\title{
Geology
}

\section{Extensional collapse of the northern Taiwan mountain belt}

Louis S. Teng

Geology 1996;24;949-952

doi: 10.1130/0091-7613(1996)024<0949:ECOTNT>2.3.CO;2

\section{Email alerting services}

\section{Subscribe}

Permission request click www.gsapubs.org/cgi/alerts to receive free e-mail alerts when new articles cite this article

click www.gsapubs.org/subscriptions/ to subscribe to Geology

click http://www.geosociety.org/pubs/copyrt.htm\#gsa to contact GSA

Copyright not claimed on content prepared wholly by U.S. government employees within scope of their employment. Individual scientists are hereby granted permission, without fees or further requests to GSA, to use a single figure, a single table, and/or a brief paragraph of text in subsequent works and to make unlimited copies of items in GSA's journals for noncommercial use in classrooms to further education and science. This file may not be posted to any Web site, but authors may post the abstracts only of their articles on their own or their organization's Web site providing the posting includes a reference to the article's full citation. GSA provides this and other forums for the presentation of diverse opinions and positions by scientists worldwide, regardless of their race, citizenship, gender, religion, or political viewpoint. Opinions presented in this publication do not reflect official positions of the Society.

\section{Notes}




\title{
Extensional collapse of the northern Taiwan mountain belt
}

\author{
Louis S. Teng Department of Geology, National Taiwan University, 245 Choushan Road, Taipei, Taiwan, Republic of China
}

\section{ABSTRACT}

As an active collision zone between the Luzon arc and the China continental margin, the Taiwan mountain belt, particularly its south-central part, is undergoing crustal shortening and rapid uplift. The northern part of the orogen is, however, subjected to crustal stretching and rifting as a result of flipping of subduction from the northwest-facing Luzon arc system to the south-facing Ryukyu arc system. Taiwan and its neighboring southern Ryukyu used to be part of the rifted China continental margin before the collision started in late Miocene time. Engineered by the northwest movement of the Philippine Sea plate in the past $5 \mathrm{~m} . y$. , the north-south-trending Luzon arc obliquely overrode the northeastsouthwest-trending continental margin and tectonized it into a collision orogen that progressively enlarged and migrated from northeast to southwest. Following the southwestpropagating collision, the north-dipping Philippine Sea plate, which was subducting beneath the Ryukyu arc, also extended westward and caused flipping of subduction in the northern part of the collision orogen. In consequence, the orogen lost the compressive support by the colliding plates and became subjected to lithospheric stretching induced by the trench suction. The collision orogen collapsed as a result of crustal thinning, and its central part foundered into a deep submerged basin. A whole spectrum of active tectonic scenarios, ranging from orogenic buildup by collision to orogenic collapse by rifting and subsidence, can be readily observed in the Taiwan-Ryukyu area and provides a vivid example for the process of orogenic collapse.

\section{INTRODUCTION}

Taiwan comprises a late Cenozoic mountain belt formed by the collision between the Luzon arc and the China continent (Ho, 1988; Teng, 1990). Owing to its youth and activeness, the Taiwan mountain belt has been widely regarded as an actualistic model for the orogenic wedge built up by accretionary processes (Dahlen and Suppe, 1988; Davis et al., 1983; Suppe, 1981). Despite the fact that collision is still active in central and southern Taiwan, the northern part of the mountain belt is no longer subjected to crustal shortening but to crustal extension (Lee and Wang, 1988; Suppe, 1984). The mountain belt itself reduces from $3000 \mathrm{~m}$ strong in central Taiwan to rolling hills in northeast Taiwan and becomes submerged in the offshore area farther to the east (Fig. 1). The diminution in altitude in association with crustal extension indicates that the northern Taiwan mountain belt has gone through the collision orogeny and is in the process of collapsing. This postcollision extensional collapse, which plays an important role in the late orogenic history of Taiwan, has, so far, received little attention. Although the extensional tectonism in northern Taiwan has been noted and interpreted in a few articles (Bowin et al., 1978; Lee and Wang, 1988; Suppe, 1984), the orogenic collapse and its underlying mechanisms have not been fully accounted for. In this paper, I outline the tectonic background of the northern Taiwan mountain belt and propose a geodynamic model for its collapse.

\section{TECTONIC BACKGROUND}

Located on the boundary between the Philippine Sea plate and the Eurasian plate, the island of Taiwan is the transform zone between the Ryukyu and Luzon arcs (Wu, 1978). The Philippine Sea plate has been moving northwest (Jolivet et al., 1990), subducting beneath the Eurasian plate under the Ryukyu arc but overriding the Eurasian plate under the Luzon arc. Engineered by this northwest movement, the northern segment of the Luzon arc collided with the China continental margin in the last 10 m.y. and pushed up the mountain belt of Taiwan (Teng, 1990). The main body of the collision orogen is believed to have reached a steady state with maximum altitude up to about $4000 \mathrm{~m}$ in central Taiwan (Suppe, 1981). Tectonized rock strata of both the China continental margin and the Luzon arc are exposed in the orogen as stacked west-facing folds and thrust sheets trending north-

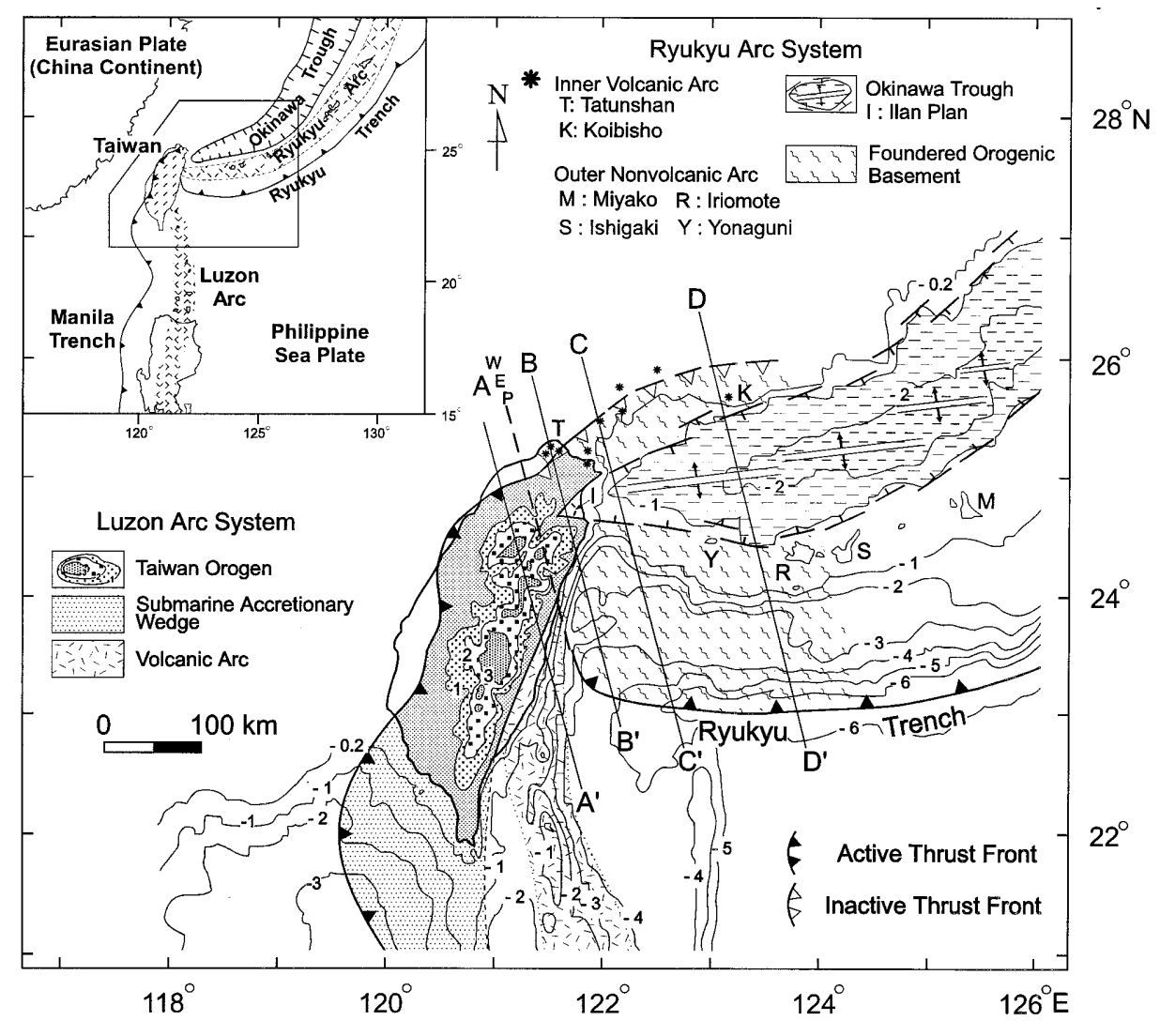

Figure 1. Tectonic framework of Ryukyu-Taiwan area. Note that across western edge of subducting Philippine Sea plate (WEP), polarity of plate convergence flipped from west-facing Luzon arc system to south-facing Ryukyu arc system. Compiled from Huang et al. (1992), Letouzey and Kimura (1986), Sibuet et al. (1987), and Teng et al. (1992). Contours in kilometres. Cross sections $A-A^{\prime}, B^{\prime}-B^{\prime}, C-C^{\prime}$, and $D^{-} D^{\prime}$ shown in Figure 2. 
Downloaded from geology.gsapubs.org on 17 September 2009

Volcanic Arc (Extinct)

\section{Okinawa Trough}

Ryukyu

Islands

Ryukyu

Trench
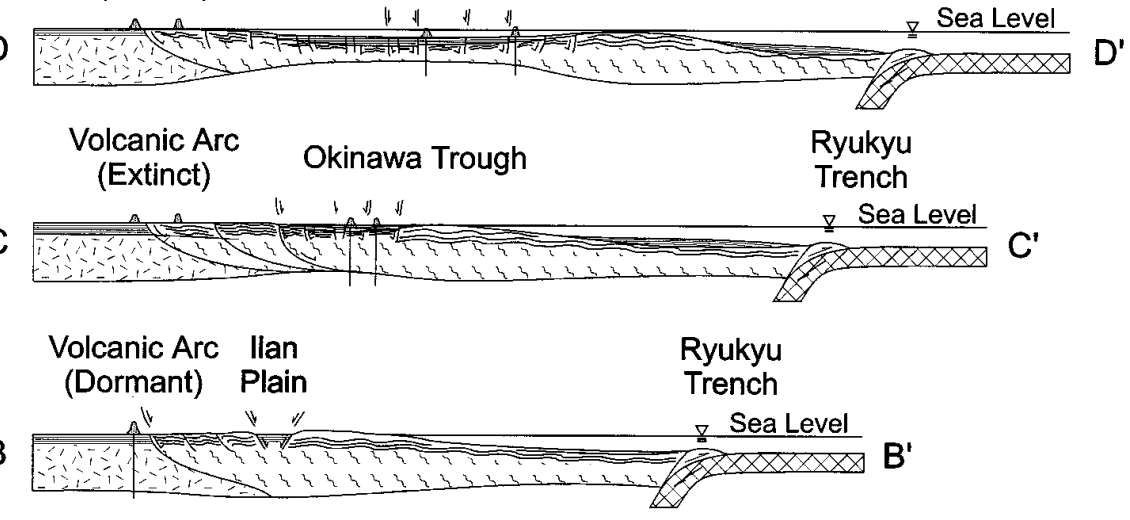

Taiwan Orogen

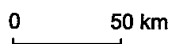

A
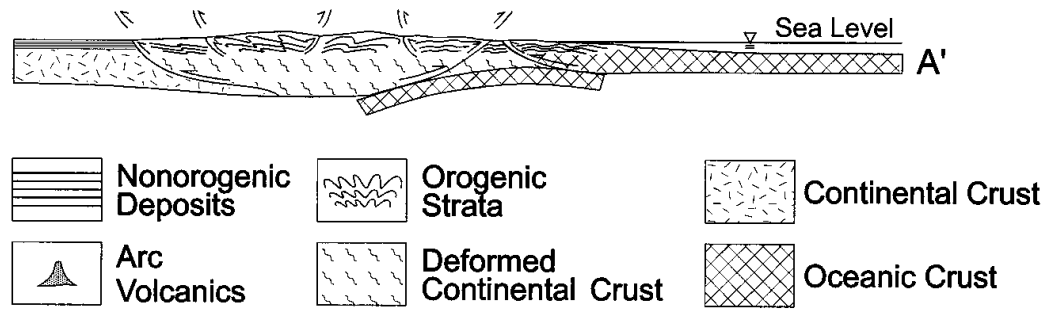

Figure 2. Crustal structure of southern Ryukyu and northern Taiwan. Note that crustal thickness and altitude of collision orogen decrease from northern Taiwan (A-A') to southern Ryukyu (D-D'). From B-B' to D-D', Ryukyu trench retreats with respect to deactivated thrust front, and Okinawa trough develops upon attenuated orogenic basement. Inner volcanic arc is potentially active in northern Taiwan (B-B') but extinct in southern Ryukyu (C-C' and $\left.D^{\prime}-D^{\prime}\right)$ where active volcanism takes place in Okinawa Trough. Surface topography and structures are exaggerated for clarity. Compiled from Hirata et al. (1991), Ho (1988), Lee et al. (1980), Letouzey and Kimura (1986), Sibuet et al. (1987), Teng et al. (1992), and Wu (1978).

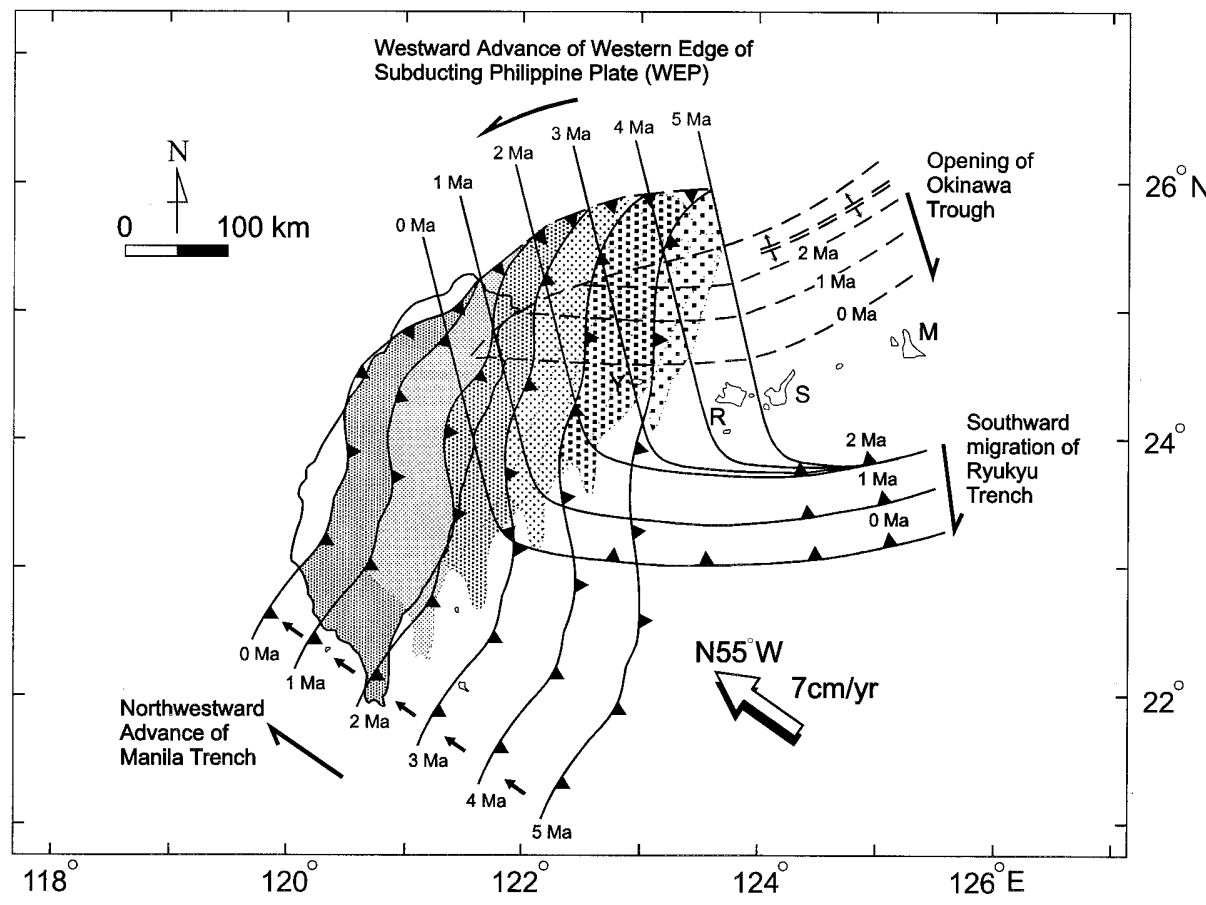

Figure 3. Plate kinematics of collision and flip of subduction in southern Ryukyu and Taiwan. Note that collision orogen (shaded area) moved westward with the advance of Manila Trench and enlarged to south with time. Okinawa Trough opened up in last 2 m.y. and pushed Ryukyu Trench to south. Symbols same as in Figure 1. Modified from Chi et al. (1981), Suppe (1984), Teng (1990), and Teng et al. (1992) on the basis of data compiled from Seno et al. (1993), Letouzey and Kimura (1986), Sibuet et al. (1987), and Teng et al. (1992). northeast-south-southwest (Ho, 1988). Collisional tectonism is still active in most of the orogen as demonstrated by the intense seismicity and prominent crustal shortening (Angelier et al., 1986; Tsai, 1986; Wu, 1978; Yu and Chen, 1994).

The steady-state orogen breaks down as it enters the northeastern part of Taiwan. In spite of the continuity of its geological charateristics, the topographic relief drops dramatically and the structural grain deflects from north-northeast-south-southwest to northeast-southwest (Suppe, 1984; Tan, 1977). Pliocene-Quaternary andesites affiliated with the Ryukyu volcanic arc unconformably cover the deformed orogenic strata (Chen, 1990; Teng et al., 1992). Extensional structures widely cut across the old contractional structures and are believed to be associated with down-faulting of Quaternary intramontane basins (Lee and Wang, 1988). Seismological data show that the north-dipping Wadatti-Benioff zone of the Ryukyu arc system underlies northern Taiwan and extensional focal mechanisms dominate in the shallow crustal earthquakes (Tsai, 1986; Yeh et al., 1991). All these features indicate that the polarity of subduction flipped in northern Taiwan, and the compressional tectonism that brought about the Taiwan orogen has been transplanted by the extensional tectonism of the Ryukyu arc (Suppe, 1984; Lee and Wang, 1988).

The deformed orogenic strata and overlying Pliocene-Quaternary andesitic volcanics and extensional structures of northeastern Taiwan can be traced offshore to the southern Ryukyu area (Huang et al., 1992; Kizaki, 1986; Letouzey and Kimura, 1986; Suppe, 1984). From the regional perspective (Figs. 1 and 2), northeastern Taiwan and southern Ryukyu can be deemed as an eastwest-trending tectonic realm that is floored with deformed rocks affiliated with the Taiwan orogen. Upon the deformed orogenic basement the modern Ryukyu arc-trench system and associated Okinawa Trough are established. There is a distinct, albeit progressive, change in topography and crustal thickness from northern Taiwan to southern Ryukyu. The elevation of the orogen diminishes from Taiwan to Ryukyu as the crustal thickness decreases from $>33 \mathrm{~km}$ to $<18 \mathrm{~km}$ (Hirata et al., 1991; Lee et al., 1980; Wu, 1978; Yen et al., 1995). The Okinawa Trough develops upon the attenuated crust of the foundered orogen and spears into the Taiwan orogen at the Ilan Plain. This eastwest change, accompanied by the transition from the compressional tectonism of the Taiwan collision orogen to the extensional tectonism of the Ryukyu arc, clearly indicates that the northern Taiwan orogen is collapsing to give way to the rifting Okinawa 


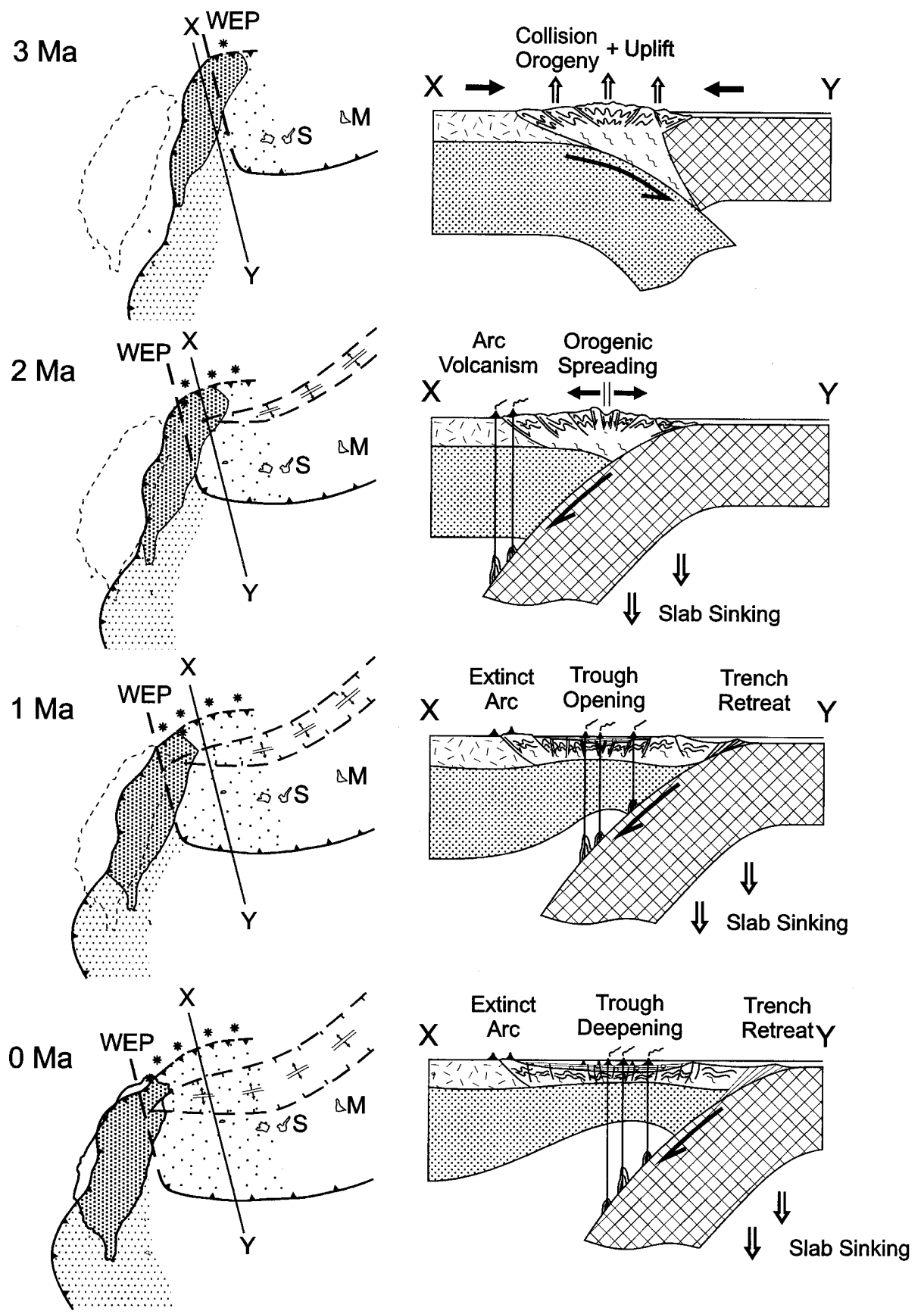

Figure 4. Late Cenozoic geodynamic evolution of southern Ryukyu. Left are kinematics excerpted from Figure 3. Right are interpreted lithospheric dynamics of section $X-Y$. The area was first subjected to collision ( $3 \mathrm{Ma}$ ) and then left in Ryukyu subduction zone as Philippine Sea plate (WEP) swept through (2 Ma). From 2 Ma to present, Ryukyu trench retreated and lithosphere of the collision orogen was stretched and thinned. The collision orogen collapsed to a rift valley, which evolves from an intramontane basin to deep Okinawa Trough. Comparable tectonic scenarios can be observed in modern Taiwan-Ryukyu area, as mimicked by sections from A-A' to $D^{-} D^{\prime}$ in Figures 1 and 2 . Symbols same as in Figures 1 and 2.

Trough. The westward-diminishing crustal extension from southern Ryukyu to northern Taiwan not only demonstrates the areal variations of orogenic collapse but reflects the temporal stages in collisional history.

\section{GEODYNAMIC EVOLUTION}

In late Miocene time, Taiwan and southern Ryukyu were part of the rifted China continental margin, which was then tecton- basement (Fig. 1), the collision can be more specifically delineated as shown by a series of kinematic scenarios (Fig. 3). In spite of minor intrinsic uncertainties, these kinematic scenarios provide a qualitative perspective of the tectonic history of the collision. The west margin of the Philippine Sea plate, marked by the north-south-trending Manila Trench, overrode the northeastsouthwest-trending China continental margin obliquely, and the collision started earlier in southern Ryukyu and progressively propagated westward into Taiwan. As the continental margin was increasingly incorporated into the subduction zone, the accretionary wedge enlarged and migrated to the southwest and eventually evolved into the collision orogen of Taiwan.

Following the southwest-migrating collision orogen, the subducting Philippine Sea plate beneath the Ryukyu arc also extended westward and crept in under the northern part of the collision orogen. As a result, the polarity of plate convergence flipped in the northern part of the orogen, and the collision was successively transplanted by subduction (Suppe, 1984). The consequence of this westward-propagating collision and flip of subduction can be well illustrated by the late Cenozoic tectonic history of southern Ryukyu (Fig. 4). During the early stage of collision, the China continental margin was shortened and thickened by the upthrusting Philippine Sea plate, and a collision orogen with pervasive contractional structures was piled up. When the collision orogen was pushed farther to the west, the subduction flipped in the northern part of the orogen so that collision ceased and arc volcanism commenced. The orogen lost the compressional support exerted by the upthrusting Philippine Sea plate and began to spread under its own weight. Hence the topographic relief was subdued and extensional structures developed. As the subduction further prevailed, trench suction induced intense lithospheric stretching (Viallon et al., 1986), which resulted in the total collapse of the collision orogen. The internal part of the orogen, where the crust is the thickest and the gravitational potential the highest, concentrated most of the extension and foundered into the rifting Okinawa trough. The magmas generated in the subduction zone were then directed into the rifting Okinawa Trough, which became the new site of arc volcanism.

Because the collision and flip of subduction have been propagating westward, the above-mentioned tectonic scenarios interpreted for southern Ryukyu can also be observed in the contemporary Taiwan-Ryukyu area (Figs. 1 and 2). Central Taiwan is currently in the collisional stage, showing 
pervasive contractional structures and prominent compressional tectonism. Northeastern Taiwan, where the polarity of subduction just flipped, exhibits a dwarfed mountain range with Quaternary arc volcanism and widespread late-orogenic extensional structures. Offshore northeastern Taiwan, having evolved into a more mature stage, is marked by a rifting collapse basin with incipient arc volcanism opening in the middle of the foundered orogen. In southern Ryukyu, the orogen collapsed to the deep Okinawa trough, which developed to its widest and deepest edifice and exhibits active crustal extension and arc magmatism.

\section{CONCLUSIONS AND DISCUSSION}

As a result of westward-propagating collision and flip of subduction, the continental margin of southern Ryukyu and northern Taiwan first underwent lithospheric thickening and then yielded to lithospheric stretching. The Taiwan mountain belt was incrementally pushed up by collision and then rapidly dismantled by rifting. A whole gamut of tectonic scenarios, from orogenic buildup in central Taiwan through incipient orogenic spreading in northeastern Taiwan to total collapse in southern Ryukyu, can be observed. The entire process is so rapid and dynamic that the pathway from orogenic buildup to orogenic collapse can be achieved within 5 m.y., and a 3000-m-high mountain range can be tectonically reduced to a 2000-m-deep basin in $<3$ m.y. Compared with other mountain ranges that have been reported to be collapsing or have collapsed (e.g., Dewey, 1988; Malavielle, 1993; Platt and Visser, 1989), Taiwan is obviously one of the most active and illustrative examples for this process.

Induced by the flip of subduction, the orogenic collapse of Taiwan is mainly triggered by the change of boundary forces. Nevertheless the body force exerted by the weight of the orogen plays an important role in dictating the site of lithospheric stretching. As shown in Figure 4, the Ryukyu volcanic arc extended into the frontal part of the collision orogen in the early stage of the flip of subduction. Generally, the volcanic arc tends to have a thicker and hotter lithosphere, which provides a favorable site for stretching and rifting (Karig, 1971; Molnar and Atwater, 1978). However, the newly invaded volcanic arc apparently did not have time to heat and thicken the lithosphere enough before significant rifting took place. The central part of the collision orogen, where the lithosphere is intensely shortened and thickened by the collision, overtakes the volcanic arc as the locus of dominant rifting. Hence the Okinawa Trough opened up in the middle of the orogen instead of the vol- canic arc. In contrast with the north-central Okinawa Trough, which developed atop or behind the volcanic arc (Letouzey and Kimura, 1986; Sibuet et al., 1987), southern Okinawa Trough is actually a fore-arc rift basin.

\section{ACKNOWLEDGMENTS}

I thank B. Clark Burchfiel, Alexander Chemenda, C. T. Lee, Greg Moore, and Gary J. Axen for critical reading and beneficial comments; Po-Ching Tai and Yen-His Lin for drafting; and the National Science Council of the Republic of China for grant support. Thanks are extended to two anonymous reviewers who offered valuable critiques that helped improve the manuscript.

\section{REFERENCES CITED}

Angelier, J., Barrier, E., and Chu, H. T., 1986, Plate collision and paleostress trajectories in a fold-thrust belt: The foothills of Taiwan: Tectonophysics, v. 125, p. 161-178.

Bowin, C., Lu, R. S., Lee, C. S., and Schouten, H., 1978, Plate convergence and accretion in Taiwan-Luzon region: American Association of Petroleum Geologists Bulletin, v. 62, p. $1645-1672$.

Chen, C. H., 1990, Igneous rocks of Taiwan: Taipei, Taiwan, Central Geological Survey, Ministry of Economic Affairs, 137 p. (in Chinese with English abstract).

Chi, W. R., Namson, J., and Suppe, J., 1981, Stratigraphic record of plate interactions in the Coastal Range of eastern Taiwan: Geological Society of China Memoir 4, p. 155-194.

Dahlen, F. A., and Suppe, J., 1988, Mechanics, growth, and erosion of mountain belts: Geological Society of America Special Paper 218, p. 161-178.

Davis, D., Suppe, J., and Dahlen, F. A., 1983, Mechanics of fold-and-thrust belts and accretionary wedges: Journal of Geophysical Research, v. 88, p. 1153-1172

Dewey, J., 1988, Extensional collapse of orogens: Tectonics, v. 7, p. 1123-1139.

Hirata, N., Kinoshita, H., Katao, H., Baba, H., Kaiho, Y., Koresawa, S., Ono, Y., and Jayashi, K., 1991, Report on DELP 1988 cruises in the Okinawa Trough, Part 3. Crustal structure of the southern Okinawa Trough: Earthquake Research Institute, University of Tokyo Bulletin, v. 66, p. 37-70.

Ho, C. S., 1988, An introduction to the geology of Taiwan: Explanatory text of the geological map of Taiwan (second edition): Taipei, Taiwan, Central Geological Survey, Ministry of Economic Affairs, 192 p.

Huang, S. T., Ting, H. H., Chen, R. C., Chi, W. R., Hu, C. C., and Shen, H. C., 1992, Basinal framework and tectonic evolution of offshore northern Taiwan: Petroleum Geology of Taiwan, no. 27 , p. $47-72$.

Jolivet, L., Huchon, P., and Rangin, C., 1990, Tectonic setting of western Pacific marginal basins: Tectonophysics, v. 160, p. 23-47.

Karig, D. E., 1971, Origin and developement of marginal basins in the western Pacific: Journal of Geophysical Research, v. 76, p. 2542-2561.

Kizaki, K., 1986, Geology and tectonics of the Ryukyu islands: Tectonophysics, v. 125, p. $193-207$.

Lee, C. S., Shor, G. G., Jr., Bibee, L. D., Lu, R. S., and Hilde, T. W. C., 1980, Okinawa Trough: Origin of a back-arc basin: Marine Geology, v. 35 , p. 219-241.
Lee, C. T., and Wang, Y., 1988, Quaternary stress changes in northern Taiwan and their tectonic significance: Geological Society of China Proceedings, v. 31, p. 154-168.

Letouzey, J., and Kimura, M., 1986, The Okinawa Trough: Genesis of a backarc basin developing along a continental margin: Tectonophysics, v. 125 , p. $209-230$.

Malavielle, J., 1993, Late orogenic extension in mountain belts: Insight from the Basin and Range and the late Paleozoic Variscan belt: Tectonics, v. 12, p. 1115-1130.

Molnar, P., and Atwater, T., 1978, Interarcspreading and Cordilleran tectonics as alternates related to the age of subducted oceanic lithosphere: Earth and Planetary Science Letters, v. 41, p. 330-340.

Platt, J. P., and Visser, R. L. M., 1989, Extensional collapse of thickened continental lithosphere: A working hypothesis for the Alboran Sea and Gibraltar arc: Geology, v. 17, p. $540-543$.

Seno, T., Stein, S., and Gripp, A. E., 1993, A model for the motion of the Philippine Sea plate consistent with NUVEL-1 and geological data: Journal of Geophysical Research, v. 98 , p. 17941-17948.

Sibuet, J. C., and 10 others, 1987, Backarc extension in the Okinawa trough: Journal of Geophysical Research, v. 92, p. 14041-14063.

Suppe, J., 1981, Mechanics of mountain building in Taiwan: Geological Society of China Memoir 4, p. 67-89.

Suppe, J., 1984, Kinematics of arc-continent collision, flipping of subduction, and back-arc spreading near Taiwan: Geological Society of China Memoir 6, p. 131-146.

Tan, L. P., 1977, Pleistocene eastward bending of the Taiwan arc: Geological Society of China Memoir 2, p. 77-84.

Teng, L. S., 1990, Geotectonic evolution of late Cenozoic arc-continent collision in Taiwan: Tectonophysics, v. 183, p. 57-76.

Teng, L. S., Chen, C. H., Wang, W. S., Liu, T. K., Juang, W. S., and Chen, J. C., 1992, Plate kinematic model for late Cenozoic arc magmatism in northern Taiwan: Journal of the Geological Society of China, v. 35, p. 1-18.

Tsai, Y. B., 1986, Seismotectonics of Taiwan: Tectonophysics, v. 125 , p. 17-38.

Viallon, C., Huchon, P., and Barrier, E., 1986, Opening of the Okinawa basin and collision in Taiwan: A retreating trench model with lateral anchoring: Earth and Planetary Science Letters, v. 80, p. 145-155.

Wu, F. T., 1978, Recent tectonics of Taiwan: Journal of Physical Earth, v. 26, p. s265-s299.

Yeh, Y. H., Barrier, E., Lin, C. H., and Angelier, J., 1991, Stress tensor analysis in the Taiwan area from focal mechanisms of earthquakes: Tectonophysics, v. 200, p. 267-280.

Yen, H. Y., and eight others, 1995, A regional gravity map for the subduction-collision zone near Taiwan: Terrestrial, Atmospheric and Oceanic Sciences, v. 6, p. 233-250.

Yu, S. B., and Chen, H. Y., 1994, Global positioning system measurements of crustal deformation in the Taiwan arc-continent collision zone: Terrestrial, Atmospheric and Oceanic Sciences, v. 5, p. 477-498.

Manuscript received February 7, 1996 Revised manuscript received June 28, 1996 Manuscript accepted July 22, 1996 